World Lumen Congress 2021 | May 26-30, 2021 |

Iasi, Romania

\title{
Digital Shadow Economy - Literature Review
}

\author{
Dan-Andrei COCA, Andreea NISTOR
}

https://doi.org/10.18662/wlc2021/13

How to cite: Coca, D.-A., \& Nistor, A. (2021). Digital Shadow Economy Literature Review. In A. Sandu (vol. ed.), Lumen Proceedings: Vol. 17 World Lumen Congress 2021 (pp. 121-130). Iasi, Romania: LUMEN Publishing House. https://doi.org/10.18662/wlc2021/13 


\title{
Digital Shadow Economy - Literature Review
}

\author{
Dan-Andrei COCA ${ }^{1 *}$, Andreea NISTOR ${ }^{2}$
}

\begin{abstract}
The virtual environment is a phenomenon that has grown exponentially in recent years, changing the way the economy evolves. Through e-commerce, social media platforms, online stores, or websites, financial resources are rolled both legally and illegally. Thus, some transactions are not accounted for or taxed, and also the concept of the digital shadow economy, defined as economic shadow activities conducted in electronic space, with no physical contact is increasingly present today. This paper aims to review and systematically analyze, through bibliometric analysis, using the Web of Science scientific platform and the VOSviewer software, the notion of digital shadow economy, determining the current state of knowledge in the field. Also, a comparative research was performed between digital shadow economy and the traditional shadow economy. The main findings reveal that digital shadow economy has a novelty character that refers to an economy based on digitized services and products, which escapes the official estimates of the GDP and the main research tendencies concern the conceptualization of the term and its main activity channels, aspects that distinguish it from traditional shadow economy. Furthermore, a thematic cluster, containing links to the digital shadow economy term can be noticed to be around cybercrimes.
\end{abstract}

Keywords: Digital shadow economy, digital shadow trade, electronic transactions, illegal ebusiness, illegal e-traders, shadow economy.

\section{Introduction}

Through the digitization and elimination of all geographical, social or cultural barriers and through a variety of services and products, currently available, online business has grown exponentially. With the help of information technology and the internet, the way to promote business opportunities has increased considerably, but at the same time, the possibility of illegal activities has increased. A path for illegal profits is also represented by online commercial transactions, which are usually guided by identity authentication, but also by the shadow digital economy, this being a current and common problem in economic activities, but also in cybernetics.

Within the digital economy, a series of criminal activities have been identified at the level of businesses, which have shaped a digital shadow economy. Dynamics and technological evolution have made it difficult to pursue this type of

\footnotetext{
${ }^{1}$ PhD Student, Ştefan cel Mare University, Suceava, Romania. E-mail: coca.danandrei@gmail.com

${ }^{2} \mathrm{PhD}$ Student, Ştefan cel Mare University of Suceava, Romania. E-mail: andreea.nistor@usm.ro
} 
economy, so that some interpretations of this concept can be identified in the literature, depending on the nature and purpose of the research. The concept of digital shadow economy recognized as underground digital economy describes a series of crimes that are committed through technology of a certain magnitude, which can be repeated worldwide (Yip et al., 2012). Therefore, digital underground economy is characterized as an online transaction, which is performed as a crime on the Internet, being determined by financial gains (Herley \& Florencio, 2010).

The costs of the digital economy are not known exactly, but according to Europol (2011), globally, the losses are extremely high, reaching 750 billion euros per year. Thus, many countries are sounding the alarm about how the digital shadow economy could be reduced in such a way as to prevent violations of privacy, but also the dynamism of individuals or legal entities in obtaining income from the digital environment.

\section{Aims of research}

The main objective of the study is to determine the state of the art of knowledge regarding the shadow digital economy, to highlight research trends from a critical perspective, thus revealing topics and areas that need further investigation and to differentiate the traditional shadow economy from the shadow digital economy.

\section{Research Methods}

Using bibliometric analysis, using the VOSviewer software tool, based on the bibliometric data exported from the Web of Science platform (WoS), the general research tendencies in the sector of digital shadow economy were revealed, but also the main body of work which revolves around the studied phenomenon.

The keywords used for identifying research on digital shadow economy on the WoS platform, were: digital shadow economy, shadow e-business, illegal e-trade, illegal e-business, digital shadow trade, by topic, all databases, all years.

In addition to that, research articles on digital shadow or underground economy were identified on the WoS platform by searching by topic the databases, as well as on Google Scholar search engine. Afterwards, a systematic critical literature review was performed on the publications retrieved.

\section{Findings}

The search on the WoS platform generated 73 publications that are mainly from the last three years (32), the first one dating from 1995. The main WoS categories are Economics, Management and Business (38). Out of the 2581 number of identified terms, 54 meet the requirement of at least 8 occurrences, and based on the calculated VOSviewer relevance score, the $60 \%$ most relevant ones (32) are those presented in Figure 1, below: 


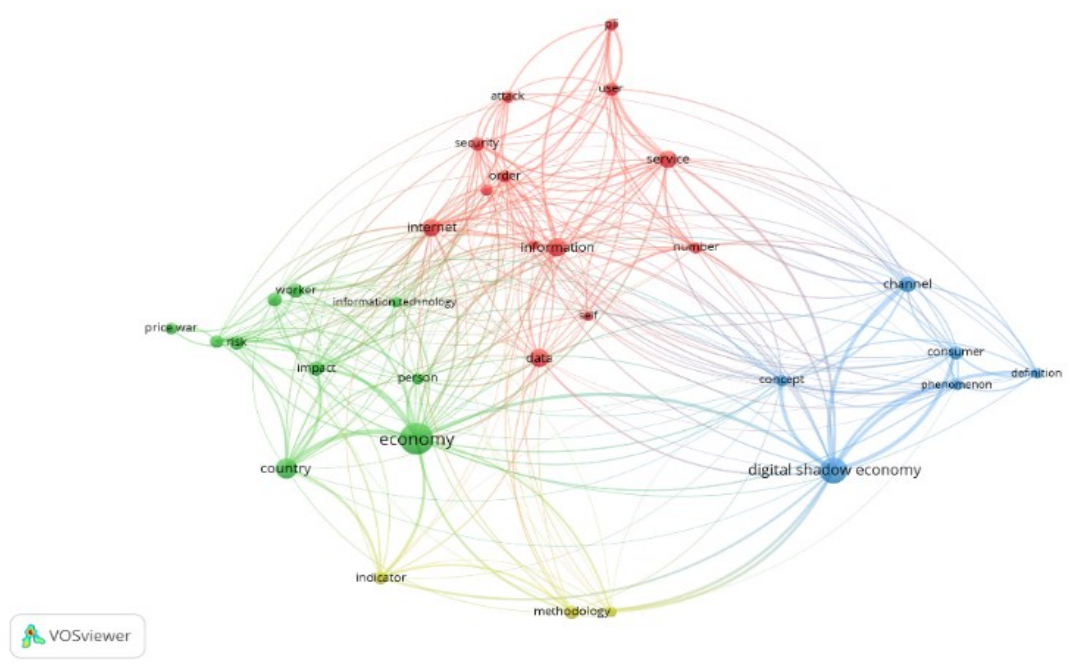

Fig. 1: Co-occurrence network of words when searching digital shadow economy by topic. Source: own generation in VOSviewer.

As shown in Figure 1, the 32 most relevant terms used in researches on digital shadow economy, can be grouped in 4 thematic clusters, having as main relevant terms, the following: (1) information, (2) economy, (3) digital shadow economy and (4) methodology.

\subsection{Digital shadow economy - current state of knowledge}

In this section, based on the research articles retrieved from the WoS platform when searching by topic digital shadow economy and Google Scholar search engine, a systematic critical literature review was performed.

As an effect of the society`s development, traditional commerce changed into e-commerce and more and more people prefer to shop on online platforms rather than physical establishments (Gaspareniene \& Remeikiene, 2016).

Factors as globalization and digitalization have consistently modified the manner in which people are working and communicating, producing changes even in the purchasing decisions, as technology is being used on a daily basis (Gasparènienè et al., 2018).

Studies on the digital shadow economy do not show multilateralism in literature, so the purpose of this paper is to systematize and analyze this phenomenon, which is growing according to Higgins (2007). The concept of digital shadow economy has hardly received an exact definition, so it is the attitude of consumers that makes the difference between what is the official and informal economies (Hill, 2007; Williams et al., 2010). This concept has the possibility to develop a series of measures, meant to control and manage properly this phenomenon (Camarero et al., 2014; Taylor, 2012).

Digital shadow economy was defined as incorporating illegal sales of goods/services online, through illegal actions, which violate several rules, to obtain material benefits (Remeikiene et al., 2018). According to the authors, as main 
characteristics of digital shadow economy it can be mentioned: electronic space for conducting activities, less control measures as compared to traditional shadow activities, undefined geographical location, communication in e-space, no physical contact, usage of e-payments, cryptocurrencies. Thus, it can be stated that such activities are very opaque and well hidden from the authorities.

Another definition of the shadow digital economy is represented by illegal physical or online actions, which are not declared at the time of reporting, but which generate profit. (Gaspareniene et al., 2016, p. 507).

Some studies found that the digital shadow economy is often reduced to studies of e-fraud and cyber activities, but also to the motivation of consumers to take part in such activities (Gaspareniene \& Remeikiene, 2015, p. 402).

According to recent research in the field (Abramowicz et al., 2011; Gaspareniene \& Remeikiene, 2016; Gaspareniene et al., 2016; Remeikiene et al., 2018) it is undebatable that the digital economy has a non-observed component, but considering the novelty of the concept, measuring its size is a challenging activity and it can be stated that estimation methods have not been developed up until this moment. As applied to the traditional shadow economy the hardest step is to isolate a series of indicators and variables able to quantify its size.

The number of illegal activities that occur online is increasing each year, thus an interest from both public and private sector to manage and develop means to prevent and control them (Gaspareniene et al., 2016; Gaspareniene et al., 2017). The scientific resources (Williams \& Nadin 2012; Schneider \& Williams, 2015) reveal the most used variables used when estimating shadow economy: direct and indirect taxation, tax rate, exports, labor force rate, GNP, GDP, expenditures and tax return.

In our opinion, a proper financial and economic profiling of the digital shadow economy should take into consideration the following: legal form, industry, risk data, owners' data, sanctions and adverse media (as Internet is everywhere).

\subsection{Definitions regarding digital shadow economy}

The evolution of technologies has led to several definitions and concepts regarding the types of activities involved in what means digital shadow economy, but a common definition of this concept has not yet been established ( $\mathrm{Yu}$ et al., 2015). Therefore, the activity of this concept includes a series of terms, meant to highlight the nature of the concept of the digital shadow economy, but also to emphasize the role of this concept as a main supplier to the consumer (Akintoye \& Araoye, 2011). In Table no. 1 we presented a series of definitions proposed by various authors, in order to understand the differences and similarities between the digital economy and the digital shadow economy. 
Table 1. Defining the concepts of digital economy and shadow economy in specialty literature

\begin{tabular}{|c|c|}
\hline Digital economy & Shadow economy \\
\hline $\begin{array}{l}\text { A transformation of all economic } \\
\text { sectors through digitalization } \\
\text { (Brynjolfsson \& Kahin, 2000) }\end{array}$ & $\begin{array}{l}\text { An activity that can be developed } \\
\text { independently of the state control and } \\
\text { accounting system (Nechaev \& } \\
\text { Mihailushkin, 2011) }\end{array}$ \\
\hline $\begin{array}{l}\text { A complex structure seen as a way to } \\
\text { achieve something tangible and less as } \\
\text { a concept, which focuses on digital } \\
\text { technologies (Elmasry et al., 2016) }\end{array}$ & $\begin{array}{l}\text { A complex process that endangers } \\
\text { socio-economic relations, operating } \\
\text { illegal activities (Williams \& Nadin, } \\
\text { 2012) }\end{array}$ \\
\hline $\begin{array}{l}\text { It has three main components: e- } \\
\text { infrastructure, e-business, and e- } \\
\text { commerce (Mesenbourg, 2001) }\end{array}$ & $\begin{array}{l}\text { Income from economic activities that } \\
\text { neglect taxation and government } \\
\text { regulations (Schneider \& Williams, } \\
2013 \text { ) }\end{array}$ \\
\hline $\begin{array}{l}\text { An economy based on digitized } \\
\text { services and products, whether it is } \\
\text { online sales, education, or information } \\
\text { services (Margherio et al., 1999) }\end{array}$ & $\begin{array}{l}\text { A hidden economy focused on the } \\
\text { production of legal or illegal goods and } \\
\text { services, which is not officially } \\
\text { estimated in GDP. (Smith, 1994) }\end{array}$ \\
\hline $\begin{array}{l}\text { An era of network intelligence, which } \\
\text { combines knowledge, intelligence, and } \\
\text { creativity to create new products and } \\
\text { services (Tapscott, 1996) }\end{array}$ & $\begin{array}{l}\text { An emigration from the established } \\
\text { way of working, being a decision } \\
\text { adopted against the official norms } \\
\text { regarding economic activity (Cassel \& } \\
\text { Caspers, 1984) }\end{array}$ \\
\hline
\end{tabular}

Source: gathered data

The terms that highlight the notion of digital shadow economy suggests online trading, aimed at profit. In other words, this term shows a violation of legal regulations in the online environment, aimed at making a profit (Ahmad, 2008). Also, the undeclared digital economy is the one that puts access to what tax evasion means, the undeclared digital economy underlines a series of regulations regarding the reporting of commercial activities, and this includes online operations (Feige \& Urban, 2008).

The consumer is an important agent, better highlighted by the concept of "digital black marketing" as opposed to traditional shadow economy, so in this regard, online trading is emphasized of fraudulent data, a series of products considered illegal and in general, highlights the concept of "cybercrime" by exploiting network technology (Yip et al., 2012). This cybercrime is characterized as a type of underground economy, which, through the development and distribution of tools for criminal behaviour, becomes industrialized (Mello, 2013). At the same time, this type of crime also targets advanced actions in the technological environment, using a series of personalized programs such as malware, attacks, bot networks, designed to threaten consumers in the public or private sector (Vlachos et al., 2011). Usually, the resources that come into the possession of digital shadow economy practitioners are those that include access to networks, space on a computer hard drive, access to financial resources, data, and even intellectual capital. 


\subsection{Cybercrime and Digital Shadow Economy}

Cybercrime is usually related to everything that involves the illegal activities of suppliers of products or services, so they generate financial resources from the digital shadow economy, but this concept should not be limited to money obtained illegally (Vlachoset al., 2011). In other words, this concept deprives consumers of obtaining certain products in a legal, declared, and accounted way (Blackledge \& Coyle, 2010). These illegal activities are found in the literature under the name of efraud. This term is perceived as the illegal use of similar digital products and services. (Taylor, 2012). The digital economy is viewed from the perspective of a credit card transaction attestation, which was stolen through online mounting (Thomas \& Martin, 2006).

The interest in the digital shadow economy started a few years ago when this concept became a goal of scientific research. Among the most well-known types of cybercrime are those that represent identity theft, often committed with the help of social networks, fraud applications, malware, which are used for antivirus scans on a particular device, but also for detecting users (Mello, 2013). The consumer seen from the perspective of the main agent is the one who engages in dysfunctional behavior, performing electronic piracy, which is the way to obtain financial resources illegally, through the Internet, but at the same time, in the opinion of the online consumer, he acts dishonestly, violating several contractual conditions to obtain dishonest profit (Amasiatu \& Shah, 2014). Most cases involving electronic fraud focus on consumers purchasing different items, whether they are clothing, gadgets or other devices at much lower prices.

Dysfunctional behavior in the electronic environment is guided by actions, meant to violate certain rules of conduct accepted by society (Harris \& Reynolds, 2003). If the traditional shadow economy covers only certain geographical areas or regions, in the digital shadow economy the geographical boundaries are exceeded because this concept includes a variety of online platforms and websites (Levi \& Williams, 2013) from which benefits can be obtained, both through social networks and through electronic auctions (Assimakopouos \& Toska, 2011; Hafezieh, 2011; Vlachos \& Minou, 2011).

\section{Discussions}

After analyzing in VOSviewer software tool the network of links for the digital shadow economy term we found the term being linked with other 18 terms, as follows: (1) concept, phenomenon, definition, consumer, channel; (2) data, internet, information, number, order, attack, security, user; (3) economy, country, person; (4) methodology, indicator.

Thus, through deductive analysis, it can be highlighted that digital shadow economy is a concept that was scarcely researched in the literature. Due to this, the main research tendency is around the definition and conceptualisation of the term, as well as around its main activity channels.

Furthermore, a thematic cluster, containing links to the digital shadow 
economy term can be noticed to be around cybercrimes (terms as: data, internet, information, number, order, attack, security, user).

The digital economy has some characteristics, which lead to changes in the fiscal principles of traditional economic activities characterized by electronic communication and electronic transactions carried out by participants in the digital market. Thus, e-commerce is based on sales, regardless of products and services, whether material or immaterial. In the digital shadow economy, consumers have the most important role in terms of demand because they act as generators, and it often happens that they do not realize the type of action they are exercising, if it is about the activity of a legal or illegal nature in the online environment, nor of the magnitude that the obtained results can generate. In this regard, many countries are struggling to find solutions and measures to prevent this type of economy.

\section{Conclusions}

Digital shadow economy is a relatively new concept that developed in symbiosis with the technological advancements and the spread of Internet and of ebusiness and e-trade activities.

As opposed to traditional shadow economy, the concept refers to economic shadow activities conducted in electronic space with no physical contact, characterised by usage of e-payments and cryptocurrencies that escape the official estimates of GDP.

Through bibliometric analysis, it can be stated that the main research tendency with regard to the digital shadow economy increased in the recent years and concerns mainly the definition and conceptualisation of the term, as well as its main activity channels.

The digital shadow economy is an ensemble, which contains a fusion of the classic with the criminal digital and can be defined as representing an economy based on digitized services and products, which escapes the official estimates of GDP.

\section{Acknowledgement}

This work is supported by project POCU 125040, entitled "Development of the tertiary university education to support the economic growth - PROGRESSIO", co-financed by the European Social Fund under the Human Capital Operational Program 2014-2020.

\section{References}

Abramowicz, W., Stolarski, P., Filipowska, A., Perkowski, B., \& Węcel, K. (2011). System for Detection of Illegal Drugs E-Trading. Legal Knowledge and Information Systems, 235, 163-164. https://doi.org/10.3233/978-1-60750-981-3-163

Ahmad, N. A. (2008). Dead men working: Time and Space in London's ('Illegal') Migrant Economy. Work, Employment and Society, 22(2), 301-318. https://doi.org/10.1177/0950017008089106 
Akintoye, K. A., \& Araoye, O. E. (2011). Combating E-Fraud on Electronic Payment System. International Journal of Computer, 25(8), 48-53.

https://doi.org/10.5120/3048-4144

Amasiatu, C. V., \& Shah, M. H. (2014). First Party Fraud: A Review of the Forms and Motives of Fraudulent Consumer Behaviours in E-Tailing. International Journal of Retail \& Distribution Management, 42(9), 805-817. https://doi.org/10.1108/IJRDM05-2013-0112

Blackledge, J. M., \& Coyle, E. (2010). PrE-Fraud Prevention Based on the SelfAuthentication of e-Documents. In L. Berntzen, F. Bodendorf, E. Lawrence \& M. Perry (Eds), Fourth International Conference on Digital Society (pp. 329-338). IEEE. https://doi.org/10.1109/ICDS.2010.66

Brynjolfsson, E., \& Kahin, B. (2000). Introduction in Understanding the Digital Economy. MIT Press.

Camarero, C., Anton, C., \& Rodriguez, J. (2014). Technological and Ethical Antecedents of E-Book Piracy and Price Acceptance: Evidence from the Spanish Case. The Electronic Library, 32(4), 542-566. https://doi.org/10.1108/EL-11-2012-0149

Cassel, D. \& Caspers, A. (1984). Ce este economia ascunsă? Conceptul şi manifestările celei de-a doua economii [What is the hidden economy? The concept and manifestations of the second economy]. Studii economice [Economic Studies] 1, 1-7.

Elmasry, T., Benni, E., Patel, J., \& Moore, J. P. (2016). Digital Middle East: Transforming the Region into a Leading Digital Economy. McKinsey \& Company.

Europol. (2011). Cybercrime as a Business: The digital underground economy [Press Releases]. https://www.europol.europa.eu/media-press/newsroom/news/cybercrimebusiness-digital-underground-economy

Feige, E. F., \& Urban, I. (2008). Measuring Underground (Unobserved, Non-Observed, Unrecorded) Economies in Transition Countries: Can We Trust GDP? Journal of Comparative Economics 36(2), 287-306. https://doi.org/10.1016/j.jce.2008.02.003

Gaspareniene, L., \& Remeikiene, R. (2015). Digital Shadow Economy: a Critical Review of the Literature. Mediterranean Journal of Social Science, 6(6), 402-409. https://doi.org/10.5901/ajis.2015.v4n3s1p653

Gaspareniene, L., \& Remeikiene, R. (2016). Economic and Demographic Characteristics of the Subjects, Operating in Digital Shadow Economy. Procedia Economics and Finance, 39, 840-848. https://doi.org/10.1016/S2212-5671(16)30253-2

Gaspareniene, L., \& Remeikiene, R. (2016). Shadow Economy Estimation Methods: Digital Shadow Economy Assessment Aspect. In Business and Management 2016 : The 9th International Scientific Conference (pp. 329-338). Vilnius Gediminas Technical University. https://doi.org/10.3846/bm.2016.34

Gaspareniene, L., \& Remeikiene, R. (2016). The Methodologies of Shadow Economy Estimation in the World and in Lithuania: Whether the Criterions Fixing Digital Shadow are Included?. Procedia Economics and Finance, 1, 753-760. https://doi.org/10.1016/S2212-5671(16)30277-5

Gasparėnienè, L., Bilan, Y., Remeikienè, R., Ginevičius, R., \& Čepel, M. (2017). The Methodology of Digital Shadow Economy Estimation. Ekonomie 20(4), 20-33. https://doi.org/10.15240/tul/001/2017-4-002 
Gaspareniene, L., Remeikiene R, Ginevicius, R., \& Skuka, A. (2016). Critical Attitude towards the Theory of Digital Shadow Economy: Literature Review and New Foundations. Terra Economicus 14(4), 156-172.

file:///C:/Users/User/Downloads/critical-attitude-towards-the-theory-of-digitalshadow-economy-literature-review-and-new-foundations.pdf

Gasparènienè, L., Remeikienè, R,. Ginevičius, R., \& Schieg, M. (2018). Adoption of MIMIC Model for Estimation of Digital Shadow Economy. Technological and Economic

Development of Economy 24(4), 1453-1465. https://doi.org/10.3846/20294913.2017.1342287

Gaspareniene, L., Remeikiene, R. \& Ginevičius R. (2018). Attitudes of European Consumers Towards Digital Shadow Economy: Lithuanian and Spanish cases. Acta Polytechnica Hungarica, 15(4), 121-142. https://doi.org/10.12700/APH.15.4.2018.4.7

Gaspareniene, L., Remeikiene, R. \& Navickas, V. (2016). The Concept of Digital Shadow Economy: Consumer's Attitude. Procedia Economics and Finance, 39, 502-509 https://doi.org/10.1016/S2212-5671(16)30292-1

Gasparènienè, L., Remeikienè, R., Sadeckas, A., \& Ginevičius R. (2016). Level and Sectors of Digital Shadow Economy: the Case of Lithuania. Entrepreneurship and sustainability issues, 4(2), 183-197 https://doi.org/10.9770/jesi.2016.4.2(6)

Hafezieh, N., Akhavan, P., \& Eshraghian, F. (2011). Exploration of Process and Competitive Factors of Entrepreneurship in Digital Space: A Multiple Case Study in Iran. Education, Business and Society. Contemporary Middle Eastern Issues, 4(4), 267-279, https://doi.org/10.1108/17537981111190051

Harris, L. C., \& Reynolds, K. L. (2003). The Consequences of Dysfunctional Customer Behavior. Journal of Service Research, 6(2), 144-161. https://doi.org/10.1177/1094670503257044

Herley C., \& Florêncio D. (2010). Nobody Sells Gold for the Price of Silver: Dishonesty, Uncertainty and the Underground Economy. In: T. Moore, D. Pym \& C. Ioannidis (Eds.) Economics of Information Security and Privacy (pp. 33-53). Springer

Higgins, G. E. (2007). Digital Piracy, Self-Control Theory, and Rational Choice: An Examination of the Role of Value. International Journal of Cyber Criminology, 1(1), 33 55. https://doi.org/10.5281/zenodo.18277

Hill, C. W. L. (2007). Digital Piracy Causes, Consequences and Strategic Responses. Asia Pacific Journal of Management, 24(1), 9-25. https://doi.org/10.1007/s10490-006-9025$\underline{0}$

Levi, M., \& Williams, M. L. (2013). Multi-Agency Partnerships in Cybercrime Reduction: Mapping the UK Information Assurance Network Cooperation Space. Information Management \& Computer Security, 21(5), 420-443. https://doi.org/10.1108/IMCS-04$\underline{2013-0027}$

Margherio, L., Henry, D., Cooke, S., \& Montes, S. (1999). The Emerging Digital Economy. Department of Commerce.

Mello, J. P. (2013). Cybercrime Fuelled by Mature Digital Underground. Identity \& Access.

Mesenbourg, T. L. (2001). Measuring the Digital Economy. US Bureau of the Census.

Nechaev, V.I., \& Mikhailushkin, P.V. (2011). The Economic Dictionary: Reference Edition. Krasnodar. 
Remeikiene, R., Gaspareniene, L., \& Schneider, F.G. (2018). The Definition of Digital Shadow Economy. Technological and Economic Development of Economy, 24(2), 696-717. https://doi.org/10.3846/20294913.2016.1266530

Schneider, F., \& Williams, C. C. (2013). The Shadow Economy. The Institute of Economic Affairs.

Smith, P. (1994). Assessing the Size of the Underground Economy: The Canadian Statistical Perspectives. Ottawa: Statistics Canada, 28, 2-23.

https://publications.gc.ca/Collection/Statcan/13-604-M/13-604-MIB1994028.pdf

Tapscott, D. (1996). The Digital Economy: Promise and Peril in the Age of Networked Intelligence. McGraw-Hill.

Taylor, S. A. (2012). Evaluating Digital Piracy Intentions on Behaviors. Journal of Services Marketing, 26(7), 472-483. https://doi.org/10.1108/08876041211266404

Thomas, R., \& Martin, J. (2006). The Underground Economy: Priceless. The USENIX Magazine, 31(6), 7-16.

https://www.usenix.org/system/files/login/articles/822/cymru.pdf

Vlachos, V., Minou, M., Assimakopouos, V., \& Toska, A. (2011). The Landscape of Cybercrime in Greece. Information Management \& Computer Security, 19(2), 113-123. https://doi.org/10.1108/09685221111143051

Williams, C. C., \& Nadin, S. (2012). Tackling the Hidden Enterprise Culture: Government Policies to Support the Formalization of Informal Entrepreneurship.

Entrepreneurship \& Regional Development, 24(9-10), 895-915. https://doi.org/10.2139/ssrn.2289947

Williams, P., Nicholas, D., \& Rowlands, I. (2010). The attitudes and behaviours of illegal downloaders. Aslib Proceedings, 62(3), 283-301. https://doi.org/10.1108/00012531011046916

Yip, M., Shadbolt, N., Tiropanis, N., \& Webber, C. (2012). The Digital Underground Economy: A Social Network. Approach to Understanding Cybercrime. Digital Futures 2012: The Third Annual Digital Economy All Hands Conference.

Yu, C., Young, M. L., \& Ju, B. C. (2015). Consumer Software Piracy in Virtual Communities: An Integrative Model of Heroism and Social Exchange. Internet Research, 25(2), 317-334. https://doi.org/10.1108/IntR-08-2013-0187 